\title{
Експериментальне обгрунтування і досвід використання ксенорогівки при лікувально-тектонічній кератопластиці у хворих із виразками рогівки різної етіології
}

\begin{abstract}
Мета роботи: обгрунтувати доцільність використання кріоліофілізованої ксенорогівки свині при лікувально-тектонічній кератопластиці у хворих із виразками рогівки різної етіології.

Матеріали і методи. В експерименті з метою вивчення ефективності різних методів консервування рогівки свині були використані різні методи консервування донорських рогівок: волога камера за В. П. Філатовим, ліофілізоване висушування, глибоке заморожування $\left(-196{ }^{\circ} \mathrm{C}\right)$ без кріопротектора, глибоке заморожування з кріопротектором, глибоке заморожування 3 кріопротектором і наступною ліофілізацією.

Експериментальна ксенокератопластика за методикою інтраламелярної кератопластики була проведена на в'єтнамських свинях і кроликах породи Шиншила. Термін спостереження за тваринами - 6 місяців. Лікувальну або лікувально-тектонічну кератопластику кератоксеноімплантатом за методикою Н. О. Пучківської проведено хворим із ускладненнями запальних захворювань рогівки та з опіковими пошкодженнями рогівки.

Результати досліджень та їх обговорення. За результатами проведених досліджень встановлено, що найкраще зберігається структура рогівки при глибокому заморожуванні з кріопротектором, а наступна ліофілізація майже не впливає на їі структуру. У результаті вивчення особливостей реакції ока на трансплантацію ксеногенних рогівок при різних методах консервування 3 наступною алотрансплантацією в рогівку свині чи ксенотрансплантацією в рогівку кролика встановлено, що реакція ока рогівки свинок на алотрансплантат донорської рогівки свині та реакція на ксенотрансплантат у рогівку кролика була незначною. За результатами клінічного застосування у хворих із виразковими ускладненнями запальних захворювань рогівки і опіків очей встановлено, що післяопераційний період відрізнявся спокійним перебігом. Термін розсмоктування ксенокератоімплантата зазвичай тривав від 3 до 8 тижнів. Повне загоєння виразки, закриття фістули з утворенням помутніння рогівки в ділянці дефекту із помірною васкуляризацією було досягнуто у всіх хворих. У всіх хворих з опіками очей вдалось зберегти рогівку від перфорації, око і світловідчуття з подальшою перспективою відновлення зору.

Найкращі результати консервування рогівки свині спостерігались при іï глибокому заморожуванні з кріопротектором та подальшою ліофілізацією. Результати клінічного застосування кератоксеноімплантата свідчать про доцільність і перспективність його застосування у хворих при виразкових ускладненнях запальних захворювань та після опікових пошкоджень рогівки.
\end{abstract}

Ключові слова: захворювання рогівки, ксенорогівка, консервування, кератоксеноімплантат.

Постановка проблеми і аналіз останніх досліджень та публікацій. Патологія рогівки посідає одне з провідних місць серед причин сліпоти і слабкого зору. Найчастіше ураження рогівки $€$ наслідком травм та опіків, що належать до найтяжчої патології органа зору. За даними ВООЗ, патологія рогівки входить до трійки основних чинників втрати зору, частка якої становить від 7 до 39 \% включно. Зокрема, травми рогівки у осіб працездатного віку в структурі первинної інвалідності становлять $29 \%$, а частота опіків очей, за даними різних авторів, становить від 6 до 38 \% усіх випадків травми органа зору [7].

Традиційні технології консервативного лікування при травматичних пошкодженнях та виразках рогівки не завжди спроможні забезпечити позитивний лікувальний ефект, що досить часто пов'язано з порушеннями репаративно-регенеративних процесів, які призводять до перфорації рогівки та загибелі ока. Тому патологія рогівки часто вимагає термінового хірургічного втручання, особливо при прогресивному лізисі і загрозі її перфорації $[1,4,5]$. Наведене вказує на те, що адекватне лікування хворих із травмою рогівки, опіками та гнійним кератитом залишається актуальною медичною, соціальною та економічною проблемою.

Одним з основних шляхів лікування хворих із патологією рогівки $є$ кератопластика. 3 урахуванням високої регенераторної здатності тканини рогівки більшість клініцистів схиляється до думки про переваги оперативного лікування вказаних хворих на засадах біологічного покриття за Н. О. Пучківською (1985). 3 цією метою використовують різні донорські матеріали, зокрема такі, як рогівка, склера, тверда мозкова оболонка, фасції, амніон тощо [1-6, 8, 9]. Пересадка рогівки $€$ найпоширенішою на даний час трансплантаційною технологією, але труднощі її реалізації в клініці становлять сутність наукової і практичної проблеми сучасної офтальмології. Серед них 
такі, як забезпечення повноцінним високоякісним донорським матеріалом і імунологічна несумісність тканин. Це тим важливіше, що в сучасних умовах на тлі різкого збільшення дорожньо-транспортного і побутового травматизму, невирішених проблемних питань правового забезпечення при отриманні алогенного матеріалу для кератопластики особливої гостроти набула проблема дефіциту донорського матеріалу.

В останні роки ми провели експериментальні дослідження потенційної можливості використання для кератопластики свинячої рогівки як такої, що за своїми морфологічними й імунологічними властивостями $€$ достатньо наближеною до рогівки людини. При розробці кріоліофілізованого кератоксеноімплантату, що зареєстровано МO3 України як виріб медичного призначення “кератоксеноімплантат” (номер державної реєстрації 9967/2010), враховано багаторічний досвід виготовлення і клінічного застосування кріоліофілізованої шкіри (свині) як ксеноімплантату для лікування головним чином опечених хворих [3].

Мета роботи: обгрунтувати доцільність використання кріоліофілізованої ксенорогівки свині при лікувально-тектонічній кератопластиці у хворих із виразками рогівки різної етіології.

Матеріали і методи. Виробництво кріоліофілізованого ксенокератоімплантату здійснено за технологією, розробленою спільно Тернопільським державним медичним університетом імені I. Я. Горбачевського й Одеським інститутом очних хвороб та тканинної терапії імені акад. В. П. Філатова АМН України (Пат. 52278 U, 2010). Технологічні етапи полягають у видаленні рогівки у щойно забитої свині, обробці за відповідних умов кріопротектором, консервуванні при наднизькій температурі (-196 ㄷ), вакуумному висушуванні, проходженні технологічного контролю, пакуванні виробу та його стерилізації радіаційним методом.

В експерименті, 3 метою вивчення ефективності різних методів консервування рогівки свині, були використані такі методи консервування донорських рогівок: волога камера за В. П. Філатовим, ліофілізоване висушування, глибоке заморожування $\left(-196{ }^{\circ} \mathrm{C}\right)$ без кріопротектора, глибоке заморожування з кріопротектором, глибоке заморожування з кріопротектором і наступною ліофілізацією.

Експериментальна ксенокератопластика за методикою інтраламелярної кератопластики була проведена на 10 в'єтнамських свинях і 10 кроликах породи Шиншила. Термін спостереження за тваринами - 6 місяців. Лікувальна або лікувально- тектонічна кератопластика кератоксеноімплантатом за методикою Н. О. Пучківської проведена 10 хворим із ускладненнями запальних захворювань рогівки і 22 хворим із опіковими пошкодженнями рогівки. Із 10 хворих із запальними захворюваннями рогівки у 5 хворих мала місце ускладнена перфорацією виразка рогівки, у 3 хворих виразка супроводжувалася загрозою перфорації рогівки (десцеметоцеле), у двох хворих виразка рогівки була ускладнена рецидивуючим кератоувеїтом. У більшості хворих з опіковими пошкодженнями рогівка мала тотальну виразку різної глибини, 3 загрозою перфорації, у більшості випадків супроводжувалась некрозом кон’юнктиви, тому їм було проведено лікувально-тектонічну кератопластику з пластикою кон’юнктиви і блефарорафією.

Результати досліджень та їх обговорення. Розроблено і досліджено ефективність низки методів консервування свинячих рогівок із обмеженою антигенною активністю. Встановлено параметри оптимальних умов для життєздатності тканини рогівки за критеріями гістоморфологічних змін на основі використання різних методів кріоконсервування для наступного створення банку рогівкових ксенотрансплантатів. Так, при дослідженні різних способів консервування рогівки встановлено, що притаманні свіжій (неконсервованій) тканині (рис. 1) основні шари, представлені клітинами переднього епітелію, боуменовою оболонкою, стромою, десцеметовою оболонкою та ендотелієм, за умов кріоконсервування в рідкому азоті, особливо з попередньою обробкою кріопротектором, зберігаються повною мірою без помітних ознак набряку чи інших пошкоджень (рис. 2).

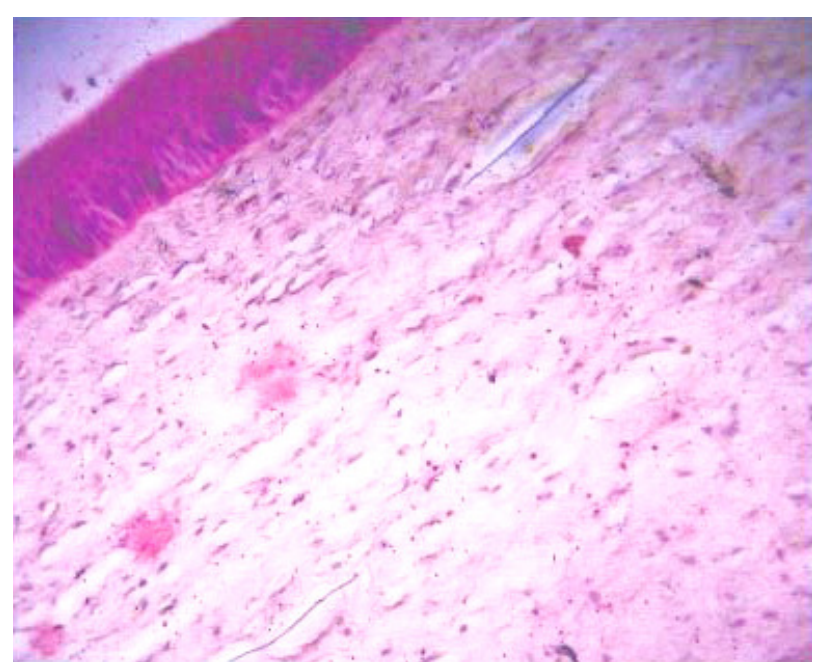

Рис. 1. Структура свіжої (неконсервованої) ксенорогівки свині, забарвлення гематоксиліном і еозином, збільшення $\times 80$. 


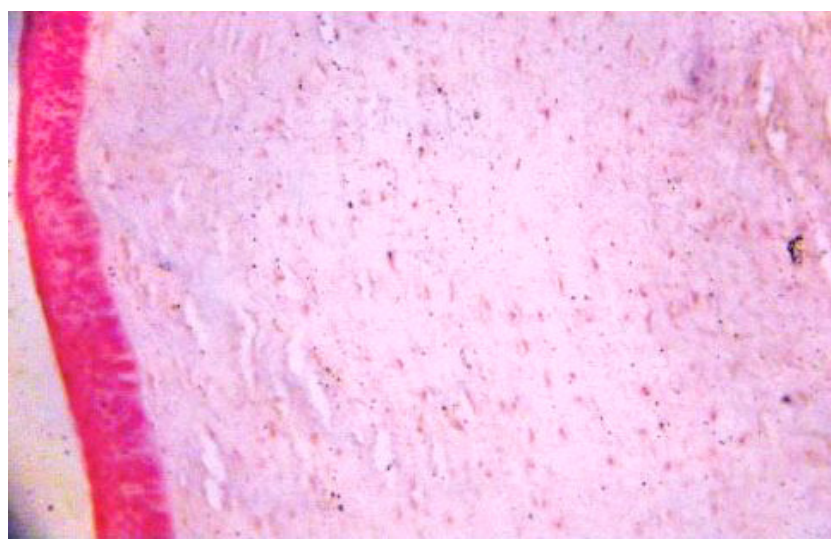

Рис. 2. Структура кріоконсервованої та обробленої кріопротектором ксенорогівки, забарвлення гематоксиліном і еозином, збільшення $\times 80$.

На противагу цьому, додаткова ліофілізація кріоконсервованої рогівки без застосування кріопротектора призводила до помірного або виразного набряку строми 3 утворенням характерних овальних або округлих порожнин, а також клітин переднього епітелію (рис. 3).

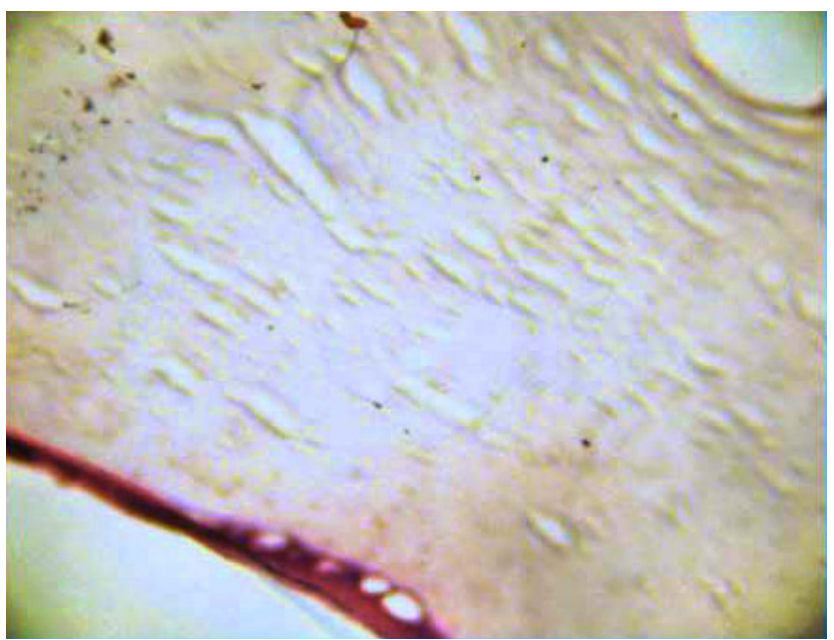

Рис. 3. Структура кріоконсервованої і ліофілізованої без кріопротектора ксенорогівки, забарвлення гематоксиліном і еозином, збільшення $\times 80$.

Вказані патологічні зсуви можуть бути нівельовані потенціюванням кріоконсервування обробкою тканинного субстрату в кріопротекторі (рис. 4).

Отже, проведеними гістоморфологічними, а також попередніми електронно-мікроскопічними дослідженнями було встановлено, що найкраще зберігається структура рогівки при глибокому заморожуванні з кріопротектором, а наступна ліофілізація майже не впливає на її структуру. Таким чином, комбінуванням кріопротекторної обробки тканинного субстрату рогівки при заморожуван-

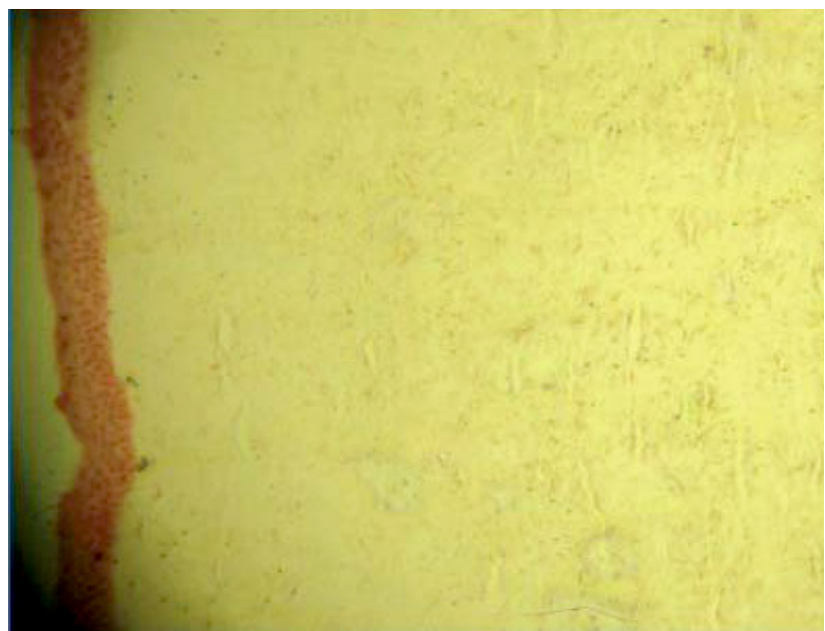

Рис. 4. Структура ліофілізованої із попередньою обробкою в кріопротекторі ксенорогівки, забарвлення гематоксиліном і еозином, збільшення $\times 80$.

ні і наступної ліофілізації відкривають перспективи досягнення оптимальних властивостей біоімплантату, надійного збереження його властивостей при довготривалому зберіганні та при транспортуванні.

У результаті вивчення особливостей реакції ока на трансплантацію ксеногенних рогівок за різних методів консервування з наступною алотрансплантацією в рогівку свині чи ксенотрансплантацією в рогівку кролика встановлено, що як реакція ока рогівки свинок на алотрансплантат донорської рогівки свині, так і реакція на ксенотрансплантат у рогівку кролика була незначною (рис. 5). У цілому вона виявилася аналогічною тій, що має місце при інтраламелярній алотрансплантації у людини.

Позитивні результати експериментального дослідження морфологічних і біофізичних власти-

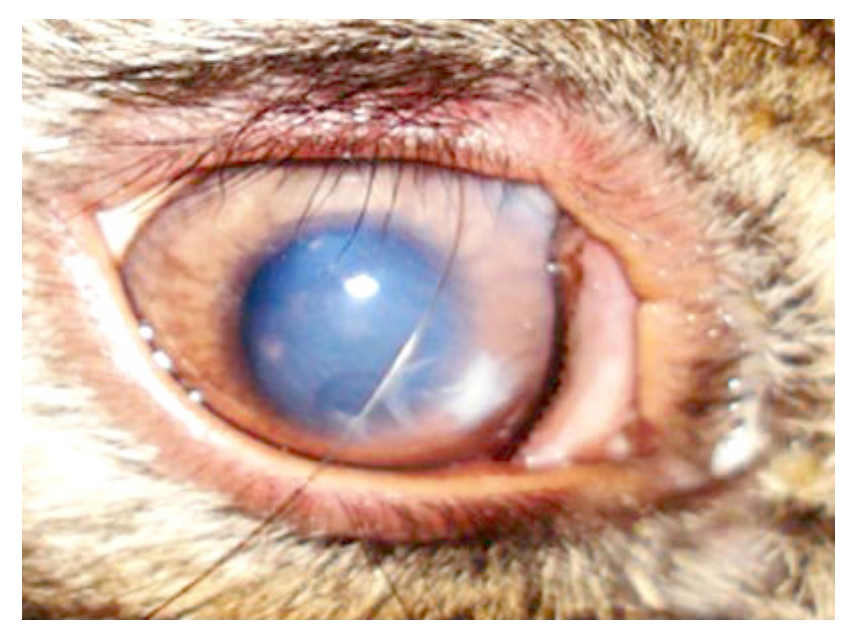

Рис. 5. Малопомітна реакція ока і рогівки кроля на ксенокератоімплантат протягом 7-ми діб. 
востей ксенокератоімплантата покладено в основу наступної серії клінічного застосування його у хворих із виразковими ускладненнями запальних захворювань рогівки і опіків очей.

На стаціонарному лікуванні після операції лікувально-тектонічної кератопластики за Н. О. Пучківською хворі з виразками рогівок запальної етіології перебували до 7 днів. Післяопераційний період відрізнявся спокійним перебігом. Термін розсмоктування ксенокератоімплантату зазвичай тривав від 3 до 8 тижнів. Повне загоєння виразки, закриття фістули з утворенням помутніння рогівки в ділянці дефекту із помірною васкуляризацією було досягнуто у всіх хворих. У всіх хворих з опіками очей вдалось зберегти рогівку від перфорації, око і світловідчуття з подальшою перспективою відновлення зору.

Клінічні і гістоморфологічні дослідження з вивчення можливості ксенотрансплантації свинячих рогівок із застосуванням способів консервування показали, що надалі донорська рогівка свині може бути рекомендована для лікувальної і тектонічної

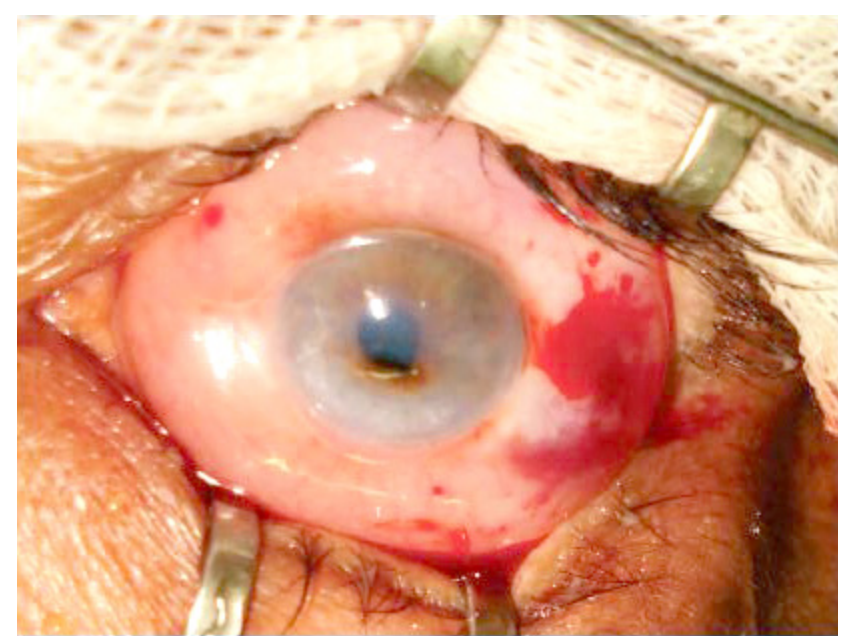

Рис. 6. Перфорація в центрі рогівки хворої людини (ускладнення виразки).

Висновки. 1. При гістоморфологічних дослідженнях в експерименті суттєвих змін у тканинах рогівки реципієнта і ало-, і ксенокератоімплантатів не виявлено, клітинна реакція несумісності тканин була незначною і залежала переважно від технології консервування.

2. Проведені клінічні і гістоморфологічні дослідження показали, що найкращі результати спо-

\section{СПИСОК ЛІТЕРАТУРИ}

1. Абрамов В. Г. Лечебная послойная кератопластика мелитированным материалом / В. Г. Абрамов, Н. А. Маркичева // Офтальмол. журн. - 1983. - Т. 258, № 2. - С. 81-83. кератопластик (рис. 6-8), а також для тривалого зберігання як об’єкта діяльності банку біотканин, що зможе вирішити сучасну проблему дефіциту донорської рогівки.

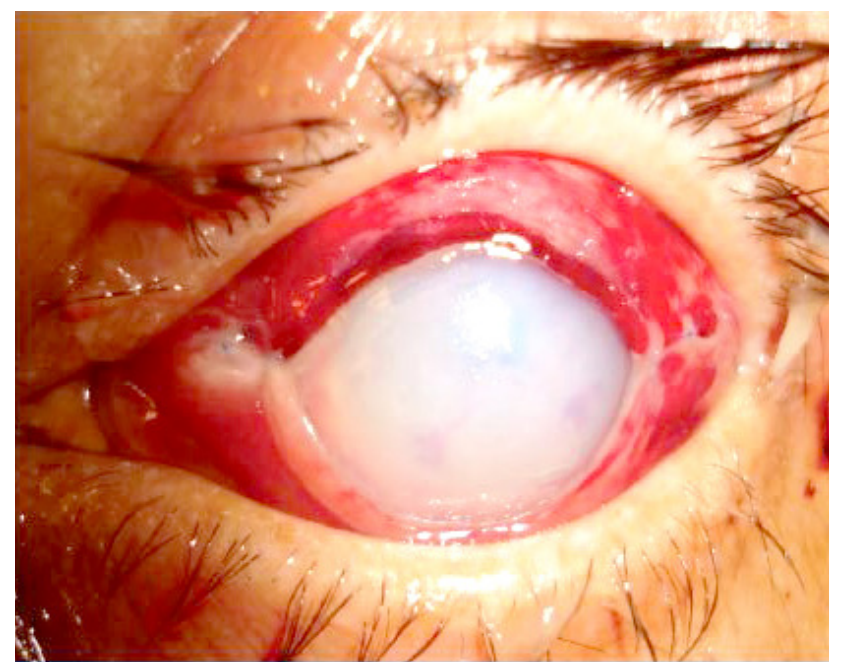

Рис. 7. Перша доба після ксенокератопластики.

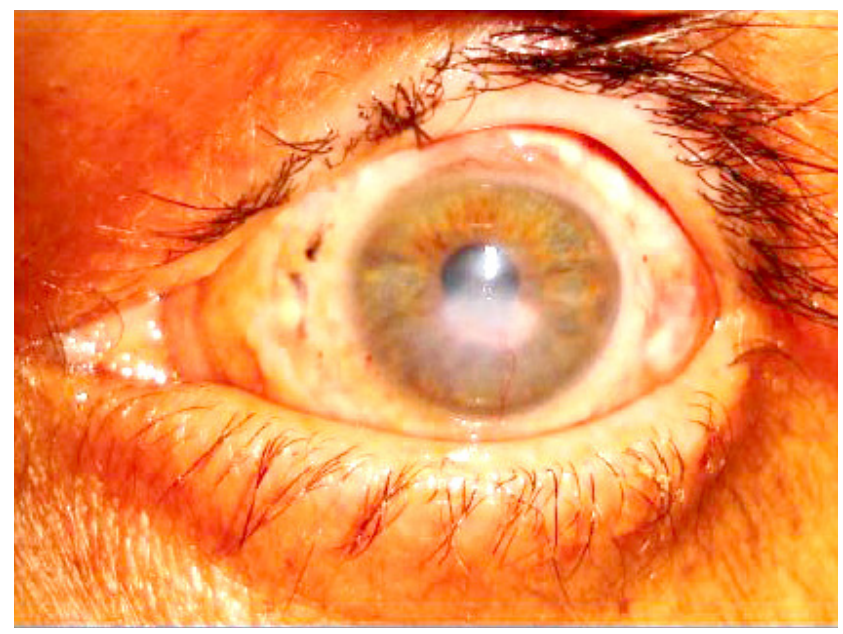

Рис. 8. Стан рогівки через 2 місяці після лікувальної ксенокератопластики.

стерігались при застосуванні донорської свинячої рогівки, консервованої при глибокому заморожуванні з кріопротектором та ліофілізацією.

3. Результати клінічного застосування кератоксеноімплантату свідчать про доцільність і перспективність його застосування у хворих при виразкових ускладненнях запальних захворювань та після опікових ушкоджень рогівки.

2. Беляев В. С. Операции на роговой оболочке / В. С. Беляев. - М. : Медицина, 1984. - 120 с.

3. Бигуняк В. В. Консервирование ауто- и ксенотрансплан- 
тата при восстановлении утраченных кожных покровов у обожженных: автореф. дис... Д-ра мед. наук. - М., 1995. - С. 28. 4. Гольдфельд Н. Г. Изучение иммуных реакцый при частичной послойной пересадке высушенной роговицы / Н. Г. Гольдфельд, Т. Л. Бажина // Вестник офтальмологии. 1967. - № 6. - С. 28-31.

5. Дронов М. М. О роговичных трансплантатах: Руководство по кератопластике / М. М. Дронов. - СПб. : Влазипресс, 1997. - 130 с.

6. Новицкий И. Я. Место трансплантации амниотической оболочки в лечении заболеваний роговицы, сопровождающихся ее неоваскуляризацией / И. Я. Новицкий // Вестн. офтальмол. - 2003. - № 6. - С. 9-11.

7. Пасєчнікова Н. В. Офтальмологічна допомога населенню України в 2009 році / Н. В. Пасєчнікова, С. О. Риков, Г. І. Степанюк // Офтальмологический журнал. - 2010. - № 5. - C. 83-88.

8. Пучковская Н. А. Биологическое покрытие как метод лечения тяжелых патологических процессов роговой оболочки // Эффективные методы диагностики и лечения при тяжелой патологии органа зрения. - Одесса, 1985. - С. 3-5.

9. Пучковская Н. А. Ожоги глаз / Н. А. Пучковская, С. А. Якименко, В. М. Непомящая. - М. : Медицина, 2001. - C. 272.

6. Novitskiy, I.Ya. (2003) Mesto transplantatsii amnioticheskoy obolochki v lechenii zabolevaniy rogovitsy, soprovozhdayushchikhsya yeye neovaskulyarizatsiyey [Place of transplantation of the amniotic membrane in the treatment of corneal diseases accompanied by its neovascularization]. Vestn. oftal. - Journal of Ophthalmology, 6, 9-11 [in Russian].

7. Pasechnikova, N.V. (2010). Oftalmologicheskaya pomoshch naseleniyu Ukrainy v 2009 godu [Ophthalmic care to the Ukrainian population in 2009]. Oftalmologicheskiy zhurnal Ophthalmologic Journal, 5, 83-88 [in Russian].

8. Puchkovskaya, N.A. (1985). Biologicheskoye pokrytiye kak metod lecheniya tyazhelykh patologicheskikh protsessov rogovoy obolochki [Biological coverage as a method of treatment of severe pathological processes of the cornea]. Effektivnyye metody diagnostiki i lecheniya pri tyazheloy patologii organa zreniya - Effective Methods of Diagnosis and Treatment with Severe Pathology of the Organ of Vision, 2, 3-5 [in Russian].

9. Puchkovskaya, N.A., Yakimenko, S.A., \& Nepomyashchaya, V.M. (2001). Ozhogi glaz [Burns of eyes]. Moscow: Meditsina [in Russian].

\section{V. TURCHIN ${ }^{1}$, N. V. PASECHNIKOVA ${ }^{2}$}

I. Horbachevsky Ternopil State Medical University ${ }^{1}$

V. Filatov Institute of Eye Diseases and Clinical Therapy²

\section{EXPERIMENTAL REASONS AND EXPERIENCE OF THE USE OF XENOROUGHT IN TREATMENT AND TECTONIC CHERAT PLASMA IN PATIENTS WITH VARIETES OF DIFFERENT ETIOLOGIES}

The aim of the work. Substantiation of expediency of use of cryolophilized xenographer of pig in medical-tectonic keratoplasty in patients with corneal ulcers of different etiology.

Materials and Methods. In the experiment, in order to study the effectiveness of different methods of preserving the pig's cornea, various methods of preserving donor crows were used: the wet chamber according to V. P. Filatov, lyophilized drying, deep freezing (-196 oC) without cryoprotectant, deep freezing with cryoprotector, deep freezing with cryoprotector and subsequent lyophilization. Experimental xenoceratoplasty, using intralamellar keratoplasty, was carried out on Vietnamese swine and rabbits of the chinchilla breed. Time of observation of animals -6 months. Therapeutic or therapeutic-tectonic keratoplasty with keratocoenomplant according to the method of N.O. Puchkivska was performed by patients with complications of inflammatory diseases of the cornea and with burn injuries of the cornea.

Results and Discussion. The conducted researches were established that the best stored structure of the cornea during deep freezing with the cryoprotectant, and the subsequent lyophilization almost does not affect its structure. As a result of studying the features of the reaction of the eye to the transplantation of xenogeneous cobblestones for different methods of preservation with subsequent allotransplantation in the cornea of the pig or xenotransplantation in the cornea of the rabbit, it was found that the reaction of the pig's cornea itself to the pig donor coronary allograft and the response to the xenograft in the cornea of the rabbit was insignificant. According to the results of clinical application in patients with ulcerative complications of inflammatory diseases of the cornea and eyes burns, it was determined that the postoperative period was characterized by a calm flow. The term xenoceratome implant resorption usually lasted 
from 3 to 8 weeks. Complete healing of the ulcer, the closure of the fistula with the formation of clouded cornea in the area of defect with moderate vascularization was achieved in all patients. All patients with burn eyes managed to keep the cornea from perforation, to keep an eye and a feeling of light with a further perspective of restoration of sight.

The best results of the canine preservation of the pig's cornea were observed with its deep freezing with the cryoprotectant and subsequent lyophilization. The results of the clinical application of keratoceno implant indicate the expediency and promise of its use in patients with ulcerative complications of inflammatory diseases and after burn injury to the cornea.

Key words: corneal disease; xenorogic; canning; keratocoenomplant.

\section{Н. В. ТУРЧИН ${ }^{1}$, Н. В. ПАСЕЧНИКОВА}

ГВУз “Тернопольский государственный медицинский университет имени И. Я. Горбачевского МЗ Украины” ГУ “Институт глазных болезней и тканевой терапии имени В. П. Филатова АМН Украины"

\section{ЭКСПЕРИМЕНТАЛЬНОЕ ОБОСНОВАНИЕ И ОПЫТ ИСПОЛЬЗОВАНИЯ КСЕНОРОГОВИЦЫ ПРИ ЛЕЧЕБНО-ТЕКТОНИЧЕСКОЙ КЕРАТОПЛАСТИКЕ У БОЛЬНЫХ С ЯЗВАМИ РОГОВИЦЫ РАЗЛИЧНОЙ ЭТИО.ЛОГИИ}

Цель работы: обоснование целесообразности использования криолиофилизированной ксенороговицы свиньи при лечебнотектонической кератопластике у больных с язвами роговицы различной этиологии.

Материалы и методы. В эксперименте с целью изучения эффективности различных методов консервирования роговицы свиньи были использованы различные методы консервирования донорских роговиц: влажная камера по В. П. Филатову, лиофилизированное высушивание, глубокая заморозка (-196 $\left.{ }^{0} \mathrm{C}\right)$ без криопротектора, глубокое замораживание с криопротектором, глубокое замораживание с криопротектором и последующей лиофилизацией.

Экспериментальная ксенокератопластика по методике интраламелярной кератопластики была проведена на вьетнамских свиньях и кроликах породы Шиншилла. Срок наблюдения за животными - 6 месяцев. Лечебная или лечебно-тектоническая кератопластика кератоксеноимплантатом по методике Н. А. Пучковской проведена больным с осложнениями воспалительных заболеваний роговицы и с ожоговыми повреждениями роговицы.

Результаты исследований и их обсуждение. По результатам проведенных исследований установлено, что лучше сохраняется структура роговицы при глубоком замораживании с криопротектором, а следующая лиофилизация почти не влияет на ее структуру. В результате изучения особенностей реакции глаза на трансплантацию ксеногенних роговиц при различных методах консервирования с последующей аллотрансплантацией в роговицу свиньи или ксенотрансплантация в роговицу кролика установлено, что реакция глаза роговицы свиней на аллотрансплантат донорской роговицы свиньи и реакция на ксенотрансплантат в роговицу кролика была незначительной. По результатам клинического применения у больных с язвенными осложнениями воспалительных заболеваний роговицы и ожогов глаз установлено, что послеоперационный период отличался спокойным течением. Срок рассасывания ксенокератоимплантата обычно длился от 3 до 8 недель. Полное заживление язвы, закрытие фистулы с образованием помутнения роговицы в области дефекта с умеренной васкуляризацией было достигнуто у всех больных. У всех больных с ожогами глаз удалось сохранить роговицу от перфорации, сохранить глаз и светоощущение с последующей перспективой восстановления зрения.

Лучшие результаты консервирования роговицы свиньи наблюдались при ее глубоком замораживании с криопротектором и последующей лиофилизацией. Результаты клинического применения кератоксеноимплантата свидетельствуют о целесообразности и перспективности его применения у больных при язвенных осложнениях воспалительных заболеваний и после ожоговых повреждений роговицы.

Ключевые слова: заболевания роговицы; ксенороговица; консервирование; кератоксеноимплантат. 